\title{
First record of Cynomops planirostris (Peters, 1865) (Chiroptera, Molossidae) from Maranhão state, Brazil, based on morphological and molecular data
}

\author{
S. B. Mendes ${ }^{a, b}$ (D), A. C. S. Lima ${ }^{b}$ (D), T. S. Reis ${ }^{b}$ (D), E. C. Fraga $a^{a, b, c}$ (D) and M. C. Barros ${ }^{a, b, c *}$ (1) \\ aPrograma de Mestrado em Ciência Animal - CCMA, Centro de Ciências Agrárias - CCA, Universidade Estadual do \\ Maranhão - UEMA, Cidade Universitária Paulo VI, CP 9, CEP 65050-150, São Luís, MA, Brasil \\ ${ }^{\text {b} L a b o r a t o ́ r i o ~ d e ~ G e n e ́ t i c a ~ e ~ B i o l o g i a ~ M o l e c u l a r ~-~ G E N B I M O L, ~ U n i v e r s i d a d e ~ E s t a d u a l ~ d o ~ M a r a n h a ̃ o ~-~ U E M A, ~}$ \\ Praça Duque de Caxias, s/n, Morro do Alecrim, CEP 65604-380, Caxias, MA, Brasil \\ 'Departamento de Química e Biologia, Centro de Estudos Superiores de Caxias - CESC, Universidade Estadual do \\ Maranhão - UEMA, Praça Duque de Caxias, s/n, Morro do Alecrim, CEP 65604-380, Caxias, MA, Brasil \\ *e-mail: mbdene@yahoo.com.br
}

Received: September 12, 2018 - Accepted: January 14, 2019 - Distributed: May 31, 2020

(With 3 figures)

\begin{abstract}
Based on morphological and molecular data, we present the first record of Cynomops planirostris for the State of Maranhão. The specimen was collected in the Inhamum Municipal Environmental Protection Area in Maranhão, Brazil and characterized morphologically as an adult male with scrotal testicles, dorsal pelage reddish chestnut, with ventral pelage slightly lighter in color, forearm length 34.70-34.80mm dental formula i:1/1, c:1/1, pm:1/2, m:3/3=26. The sequence of the Cytochrome Oxidase I subunit (COI) molecular marker confirmed the morphological diagnosis of the specimen as C. planirostris with significant similarities. The combined analysis of both morphological and molecular confirmed the occurrence of C. planirostris in the Brazilian state of Maranhão, in the Cerrado biome and records extends the known geographic distribution of the species by $411.30 \mathrm{~km}$.
\end{abstract}

Keywords: bat, morphology, DNA, cerrado.

\section{Primeiro registro de Cynomops planirostris (Peters, 1865) (Chiroptera, Molossidae) para o Estado do Maranhão, com base em dados morfológicos e moleculares}

\begin{abstract}
Resumo
Com base em dados morfológicos e moleculares apresenta-se o primeiro registro de Cynomops planirostris para o Estado do Maranhão. O espécime foi coletado na Área de Proteção Ambiental Municipal do Inhamum, no Maranhão, Brasil e caracterizado morfologicamente como um macho adulto com testículos escrotal, coloração da pelagem dorsal castanho avermelhado, pelagem ventral levemente mais clara, comprimento do antebraço variando de 34,70-34,80mm, fórmula dentária: i:1/1, c:1/1, pm:1/2, m:3/3=26. A sequência do marcador molecular Citocromo Oxidase subunidade I (COI) confirmou a diagnose morfológica do espécime com C. planirostris com significante similaridade. A combinação dos dados morfológicos e moleculares confirmou a ocorrência da espécie C. planirostris para o estado brasileiro do Maranhão, no bioma Cerrado e registra a distribuição geográfica da espécie em $411.30 \mathrm{Km}$.
\end{abstract}

Palavras-chave: morcego, morfologia, DNA, cerrado.

\section{Introduction}

The genus Cynomops, described by Thomas in 1920, is a member of the family Molossidae, part of the order Chiroptera. Five species are known to occur in Brazil (Reis et al., 2006, 2011, 2013) - Cynomops abrasus (Temminck, 1827), Cynomops greenhalli, Goodwin, 1958, Cynomops milleri (Osgood, 1914), Cynomops paranus (Thomas, 1901), and Cynomops planirostris (Peters, 1866).

The morphology of Cynomops planirostris is characterized by small ears, smaller than the head, narrow and well-separated, with the internal border overlaying the head; upper margin of the nostrils smooth, without warts; conspicuous, oval-shaped anti-tragus; dorsal pelage clear and opaque, reddish chestnut; ventral pelage ranging from slightly lighter in color than the dorsum to whitish areas on the chest and belly. Like other molossids, C. planirostris 
is insectivorous, presenting a diet based on large and small insects (Ésberard and Bergallo, 2008). The males are larger than the females. The species is found between Panama and Argentina (Reis et al., 2013).

In Brazil, the species has been recorded in the following states (Reis et al., 2013; Santos et al., 2015): Espírito Santo (Ruschi, 1951), Mato Grosso (Pine et al., 1970), São Paulo (Vizotto and Taddei, 1976), Pernambuco (Mares et al., 1981), Distrito Federal (Sá, 1998), Mato Grosso do Sul (Pulchério-Leite et al., 1998), Minas Gerais (Pedro and Taddei 1998), Goiás (Rodrigues et al., 2002), Paraná (Miretzki, 2003), Bahia (Faria et al., 2006), Ceará (Fabián, 2008), Sergipe (Rocha et al., 2010), Paraíba (Feijó and Langguth, 2011), Piauí (Novaes et al., 2013), Amapá (Silva et al., 2013), Roraima (Capaverde-Junior et al., 2014), and Tocantins (Lapenta and Bueno, 2015).

The mitochondrial COI marker has been widely used for the molecular identification of vertebrates. This marker consists of a short fragment of 650 nucleotides, originating at the 5' extremity of the mitochondrial Cytochrome Oxidase subunit I (COI) gene. Hebert et al. $(2003 \mathrm{a}, \mathrm{b})$ originally proposed the use of this marker for the identification of species.

In the present study, a specimen of C. planirostris was identified using morphological and molecular analyses. The specimen was collected in Maranhão, and represents the first record from this state, extending its known distribution in Brazil.

\section{Material and Methods}

The $C$. planirostris specimen was collected in the Cerrado savanna of the Inhamum Municipal Environmental Protection Area (APA Inhamum), in the municipality of Caxias, located in the eastern mesoregion of the Brazilian state of Maranhão (04 53 '30' S, 4324'53' W). The APA Inhamum has a total area of $5,196.77 \mathrm{~km}^{2}$ (Albuquerque, 2012). The region's climate is dry sub-humid, with a mean temperature of $27^{\circ} \mathrm{C}$, and the predominant vegetation is semi-deciduous seasonal forest with dense stands of babaçu palm in some areas (Conceição et al., 2012). Two other types of vegetation are also found within the APA Inhamum. One is gallery forest found adjacent to the Inhamum stream, with a predominance of large trees, and the other is typical open Cerrado savanna with small, contorted trees and grassland (Conceição et al., 2007; Barros, 2012).

The C. planirostris specimen was collected near the stream using 3-m high mist-nets (12 m long, with a $25 \mathrm{~mm}$ mesh) which were fixed to poles fixed in the ground. The specimen was taken to the Genetic and Molecular Biology Laboratory (GENBIMOL) at the Caxias campus of Maranhão State University (UEMA), where it was photographed, euthanized, identified, weighed, sexed, and measured using $300 \mathrm{~mm}$ digital calliper, and tissue samples were collected (and stored in microbes with 70\% alcohol).

The age class (juvenile or adult) of the specimen was determined from its morphological characters, with the testicles being found in a scrotal position. The specimen was fixed in 10\% formalin and conserved in 90\% alcohol. A series of measurements were taken: right forearm (RF), left forearm (LF), ear (E), tragus (T), foot (F), and tail (T). Taxonomic identification was based on the classification keys of Gregorin and Taddei (2002) and Reis et al. (2011, 2013). The voucher specimen is deposited in the Mastozoology Collection of the Federal University of Paraíba under catalog number UFPB 9821. This study was authorized by the Chico Mendes Institute for Biodiversity Conservation (ICMBio) through license IBAMA/SISBIO: 42670-3.

The DNA of the muscle tissue was extracted using the Wizard Genomic DNA Purification kit (Promega), following the maker's instructions. The mitochondrial Cytochrome Oxidase subunit I (COI) gene was amplified by Polymerase Chain Reaction (PCR) using the primers LCO-1490 and HCO-2198 described by Folmer et al. (1994). The sample was sequenced by the didesoxyterminal method (Sanger et al., 1977) with the Big Dye kit in a DNA ABI Prism ${ }^{\mathrm{TM}} 3500$ automatic sequencer (Applied Biosystems, USA).

The sequence was edited and aligned in BIOEDIT 7.0 (Hall, 1999), and plotted in the BOLD (Barcode of Life Data) Systems v3 bioinformation platform (Ratnasingham and Hebert, 2007) to verify the identification of the species by comparison with sequences existing in the system.b

\section{Results and Discussion}

The specimen of $C$. planirostris recorded in the present study was identified as an adult male with scrotal testicles, dorsal pelage reddish chestnut, with lighter ventral pelage, forearm length of $34.70-34.80 \mathrm{~mm}$, dental formula: $\mathrm{i}: 1 / 1$, $\mathrm{c}: 1 / 1, \mathrm{pm}: 1 / 2, \mathrm{~m}: 3 / 3=26$ (Figure 1). The morphological identification is consistent with the characteristics defined by Gregorin and Taddei (2002) and Reis et al. (2011, 2013). The specimen confirms the occurrence of this species in the Brazilian state of Maranhão and extends its known distribution by $411.30 \mathrm{~km}$ (Figure 2).

The analysis of the COI molecular marker confirmed the morphological diagnosis of the specimen as C. planirostris. A sequence of 645 base pairs was obtained, with significant similarities being found with the C. planirostris sequences deposited in the BOLD platform (Figure 3 ).

Cynomops planirostris is very similar to C. paranus and $C$. abrasus, but is smaller, with shorter forearms and tail, and a distinct coloration pattern (Simmons and Voss, 1998). Cynomops paranus is more darkly and homogeneously colored, with more sheeny pelage, both ventrally and dorsally. Cynomops abrasus has a smaller cranium than C. planirostris (Gregorin and Taddei, 2002; Reis et al., 2011).

Given its ample distribution, C. planirostris is found in all Brazilian biomes, except the Pampas grasslands (Santos et al., 2015). While the APA Inhamum has a diverse bat fauna, the exact species richness is still unclear. Olímpio et al. (2016) added 13 new species to the inventory of bat species of the Cerrado ecosystems of Maranhão, 


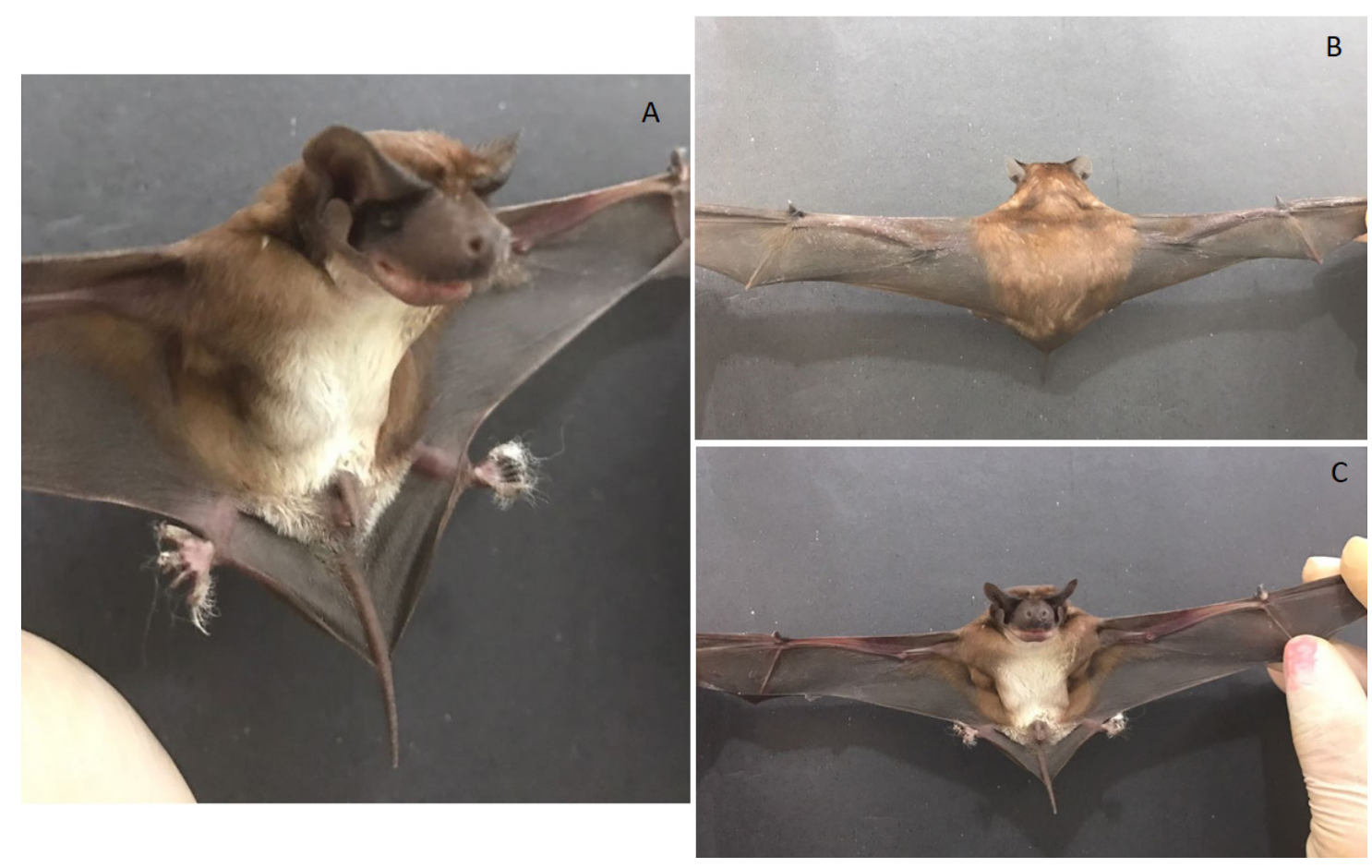

Figure 1. Cynomops planirostris from the Cerrado savanna of Maranhão, Brazil (Inhamum Municipal Environmental Protection Area). (A) lateral view; (B) dorsal view, and (C) ventral view.

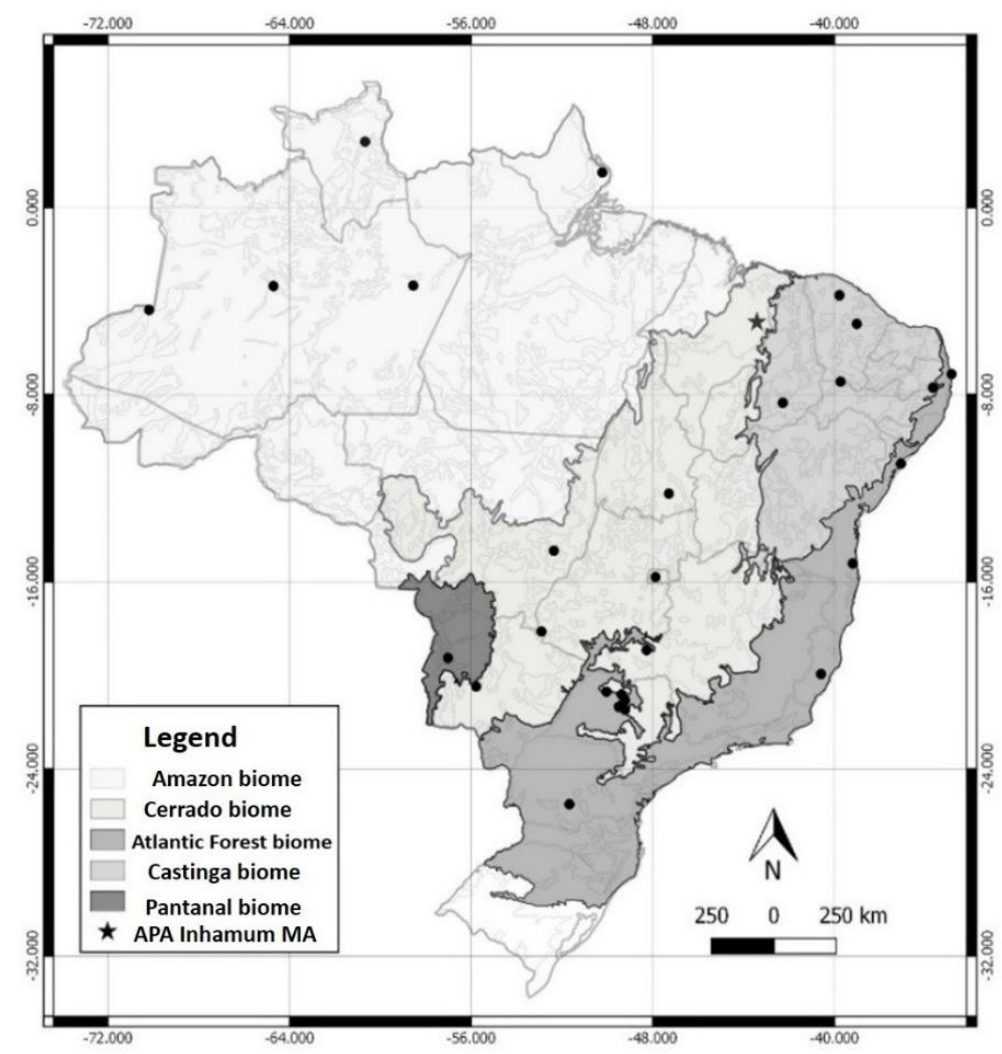

Figure 2. Occurrence localities of C. planirostris in Brazil. The star indicates the site of the present record, the first known occurrence of the species in the state of Maranhão. The points indicate the occurrence of the species for Brazil. Source: the authors. 


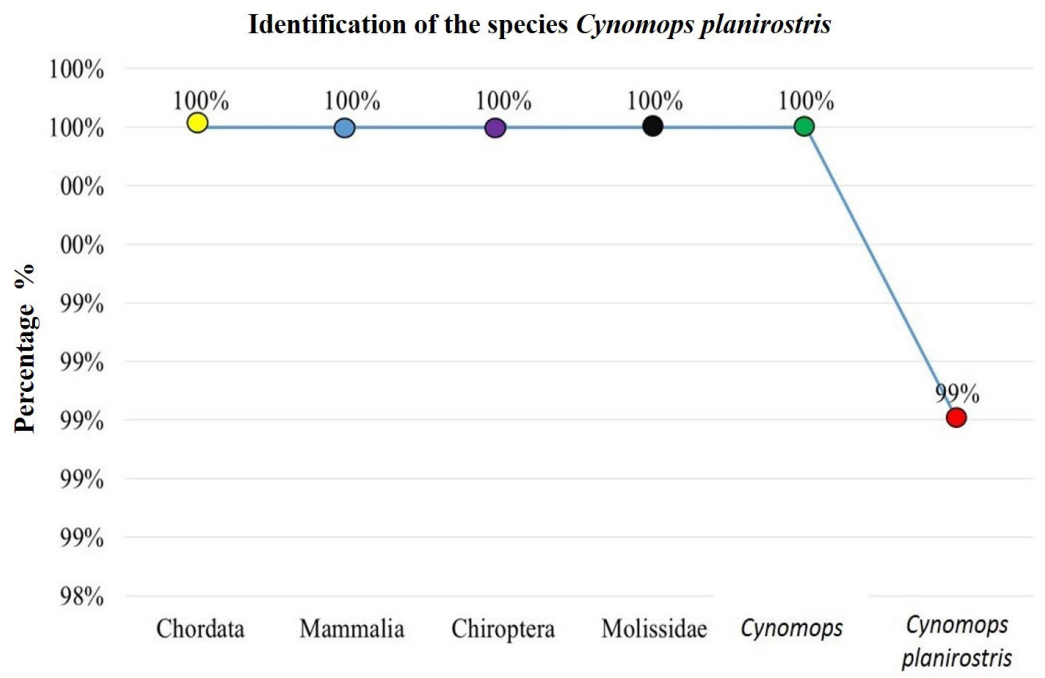

Figure 3. Percentage similarity of the C. planirostris sample with sequences retrieved from the BOLD platform.

including the APA Inhamum, although the occurrence of C. planirostris at this site was not recorded. The molossids are considered to be the bats that fly at the highest levels, above the forest canopy, and are thus captured in mist-nets only rarely, which contributes to the disproportionately reduced sampling of these species in inventories and the relative lack of biological and even taxonomic data (Marchesin et al., 2008). Besides the reduction of habitats resulting from human activities, which promotes the disappearance of species (Reis et al., 2012).

\section{Conclusion}

The combined analysis of both morphological and molecular confirmed the occurrence of $C$. planirostris in the Brazilian state of Maranhão, in the Cerrado biome. This amplifies substantially the known distribution of this species in Brazil, and in this biome, in particular.

\section{Acknowledgements}

We are grateful to the Maranhão State Foundation for Research and Scientific and Technological Development (FAPEMA).

\section{References}

ALBUQUERQUE, A.L., 2012. Riacho ponte e a área de proteção ambiental municipal do Inhamum, Caxias MA. In: M. C. BARROS, org. Biodiversidade da área de proteção ambiental municipal Inhamum. São Luís: UEMA, cap. 6, pp. 107-116.

BARROS, M.C., 2012. Biodiversidade da área de proteção ambiental do Inhamum. São Luís: UEMA, 142 p.

CAPAVERDE-JÚNIOR, U. D., PACHECO, S. M. and DUARTE, M. E., 2014. Murciélagos (Mammalia: Chiroptera) del área urbana del município de Boa Vista, Roraima, Brasil. Barbastella, vol. 7, no. 1, pp. 1-6. http://dx.doi.org/10.14709/BarbJ.7.1.2014.03.
CONCEIÇÃO, G.M., FERNANDES, R.S., BRITO, E.S. and DE PAULA-ZÁRATE, E.L., 2007. Diversidade florística de pteridófitas da área de preservação ambiental do Inhamum, Caxias, Maranhão, Brasil. Revista Brasileira de Biociências, vol. 1 , no. 5, pp. 411-413

CONCEIÇÃO, G.M., RUGGIERI, A.C., SILVA, E. O., NUNES, C. S., GALZERANO, L. and NERES, L. P., 2012. Flórula fanerogâmica da área de proteção ambiental Municipal Inhamum, Caxias MA, Brasil. In: M. C. BARROS, org. Biodiversidade da área de proteção ambiental Municipal Inhamum. São Luis: UEMA, cap. 2, pp. 22-24.

ESBÉRARD, C.E.L. and BERGALLO, H.G., 2008. Do bigger bats need more time to forage? Brazilian Journal of Biology = Revista Brasileira de Biologia, vol. 68, no. 4, pp. 819-822. http:// dx.doi.org/10.1590/S1519-69842008000400017. PMid:19197500.

FABIÁN, M.E., 2008. Quirópteros do bioma Caatinga, no Ceará, Brasil, depositados no Museu de Ciências Naturais da Fundação Zoobotânica do Rio Grande do Sul. Chiroptera Neotropical, vol. 14 , no. 1 , pp. 354-359.

FARIA, D.B., SOARES-SANTOS, B. and SAMPAIO, E., 2006. Bats from the Atlantic rainforest of southern Bahia, Brazil. Biota Neotropica, vol. 6, no. 2, pp. 1-13. http://dx.doi.org/10.1590/ S1676-06032006000200022.

FEIJÓ, J.A. and LANGGUTH, A., 2011. Lista de Quirópteros da Paraíba, Brasil com 25 novos registros. Chiroptera Neotropical, vol. 17 , no. 2, pp. 1055-1062.

FOLMER, O., BLACK, M., HOEH, W., LUTZ, R., VRIJENHOEK, R., 1994. DNA primers for amplification of mitochondrial cytochrome c oxidase subunit I from diverse metazoan invertebrates. Molecular Marine Biology Biotechnology, vol. 3, no. 5, pp. 294-299.

GREGORIN, R. and TADDEI, V.A., 2002. Chave artificial para a identificação de Molossideos brasileiros (Mammalia, Chiroptera). Journal Neotropical of Mammalogy, vol. 9, no. 1, pp. 13-32.

HALL, T.A., 1999. Bio Edit: a user-friendly biological sequence alignment editor and analysis. USA: Department of Microbiology, North Carolina State University. 
HEBERT, P.D.N., CYWINSKA, A., BALL, S.L. and DEWAARD, J.R., 2003a. Biological identifications through DNA barcodes. Proceedings of the Royal Society of London, vol. 270, no. 1512, pp. 313-322. http://dx.doi.org/10.1098/rspb.2002.2218. PMid:12614582.

HEBERT, P.D.N., RATNASINGHAM, S. and DEWARD, J. R., 2003b. Barcoding animal life: cytochrome c oxidase subunit 1 divergences among closely related species. In: Proceedings of the Royal Society - Biological Sciences, 2003, London. London: Royal Society, vol. 270, pp. 96-99.

LAPENTA, M. and BUENO, A.D.A., 2015. Checklist of bats (Mammalia, Chiroptera) from Tocantins and Bahia, Brazil: a gradient from Cerrado, Caatinga and Atlantic Forest. Check List, vol. 11, no. 4, pp. 1-7. http://dx.doi.org/10.15560/11.4.1673.

MARCHESIN, S.R.C., BEGUELINI, M.R., FARIA, K.C., MOREIRA, P.R.L. and MORIELLE-VERSUTE, E., 2008. Assessing genetic variability in bat species of Emballonuridae, Phyllostomidae, Vespertilionidae, and Molossidae families (Chiroptera) by RFLP-PCR. Journal Genetics and Molecular Research, vol. 7, no. 4, pp. 1164-1178. http://dx.doi.org/10.4238/ vol7-4gmr503. PMid:19048495.

MARES, M. A.., WILliG, M. R., STREILEIN, K. E., and LACHER, T. E., 1981. The mammals of northeastern Brazil: a preliminary assessment. Annals of the Carnegie Museum, vol. 50, no. 4, pp. 81-137.

MIRETZKI, M., 2003. Morcegos do Estado do Paraná, Brasil (Mammalia, Chiroptera): riqueza de espécies, distribuição e síntese do conhecimento atual. Papéis Avulsos de Zoologia, vol. 43, no. 6, pp. 101-138. http://dx.doi.org/10.1590/S003110492003000600001 .

NOVAES, R.L.M.R.S., LAURINDO, M.B., OLIVEIRA, C.R., BARRETO, C.D.R. and AVILLA, L.D.S., 2013. First record of two Molossidae bats (Chiroptera, Molossidae) from Piauí state and distributional review for Brazil. Check List, vol. 9, no. 3, pp. 610-613. http://dx.doi.org/10.15560/9.3.610.

OLÍMPIO, P.M., VENTURA, M.C.S., MASCARENHAS, M.J.O., NASCIMENTO, D.C., ANDRADE, F.A.G., FRAGA, E.C. and BARROS, M.C., 2016. Bat fauna of the Cerrado savanna of eastern Maranhão, Brazil, with new species occurrences. Biota Neotropica, vol. 16, no. 3. http://dx.doi.org/10.1590/1676-0611BN-2015-0089.

PEDRO, W.A. and TADDEI, V.A., 1998. Bats from southwestern Minas Gerais, Brazil (Mammalia: chiroptera). Chiroptera Neotropical, vol. 4, no. 1, pp. 85-88.

PINE, R.H., BISHOP, I.R. and JACKSON, R.L., 1970. Preliminary list of mammals of the Xavantina/Cachimbo expeditions (Central Brazil). Transactions of the Royal Society of Tropical Medicine and Hygiene, vol. 64, no. 5, pp. 668-670. http://dx.doi. org/10.1016/0035-9203(70)90003-9. PMid:5533321.

PULCHÉRIO-LEITE, A., TADDEI, V. A. and MENEGHELLI, M., 1998. Morcegos (Chiroptera, Mammalia) dos Pantanais de Aquidauana e da Nhecolândia, Mato Grosso do Sul. I. Diversidade de espécies. Ensaios e Ciência, vol. 2, no. 2, pp. 149-163.

RATNASINGHAM, S. and HEBERT, P. D. N., 2007. Bold: the barcode of life data system. Molecular Ecology Notes, vol. 7, no. 3, pp. 355-364. https://doi.org/10.111/j.1471-8286.2007.01678.x.

REIS, N. R., FREGONEZI, M. N., PERACCHI, A.L. and SHIBATTA, O. A., 2013. Morcegos do Brasil: guia de campo. Rio de Janeiro: Techinical Books, pp. 252.
REIS, N.R., GALLO, P.H., PERACCHI, A.L., LIMA, I.P. and FREGONEZI, M.N., 2012. Sensitivity of populations of bats (Mammalia: Chiroptera) in relation to human development in northern Paraná, southern Brazil. Brazilian Journal of Biology = Revista Brasileira de Biologia, vol. 72, no. 3, pp. 511-518. http:// dx.doi.org/10.1590/S1519-69842012000300014. PMid:22990822.

REIS, N.R., PERACCHI, A.L., PEDRO, W.A. E. and LIMA, I.P., 2011. Mamiferos do Brasil. 2. ed. Londrina: Nelio R. dos Reis, pp. 439.

REIS, N.R., PERACCHI, L.A. and PEDRO, A.W. 2006. Ordem Chiroptera. In: N. R. REIS, A. L. PERACCHI, W. A. PEDRO and I. P. LIMA. Mamíferos do Brasil. Paraná: Edição do Autor, pp. 155-234.

ROCHA, P.A., MIKALAUSKAS, J.S., GOUVEIA, S.F., SILVEIRA, V.V.-B. and PERACCHI, A.L., 2010. Morcegos (Mammalia, Chiroptera) capturados no Campus da Universidade Federal de Sergipe, com oito novos registros para o estado. Biota Neotropica, vol. 10, no. 3, pp. 183-188. http://dx.doi.org/10.1590/ S1676-06032010000300021

RODRIGUES, F.G.H.L., SILVEIRA, A.T.A., JÁCOMO, A.P., CARMIGNOTTO, A.M.R., BEZERRA, D.C., COELHO, H., GARBOGINI, J., PAGNOZZI, J. and HASS, A., 2002. Composição e caracterização da fauna de mamíferos do Parque Nacional das Emas, Goiás, Brasil. Revista Brasileira de Zoologia, vol. 19, no. 2, pp. 589-600. http://dx.doi.org/10.1590/S010181752002000200015 .

RUSCHI, A., 1951. Morcegos do estado do Espírito Santo: introdução e considerações gerais. Santa Teresa: INMA, pp. 16. Boletim do Museu de Biologia Professor Mello Leitão, Série Zoologia, vol. 1, no. 1.

SÁ, H.B.P., 1998. Diversidade de quirópteros na área de proteção ambiental de Cafuringa, Distrito Federal. Brasília: Universidade de Brasília, 53 p. Dissertação de Mestrado.

SANGER, F., NICKLEN, S. and COULSON, A.R., 1977. DNA sequencing with chain-terminating inhibitors. Proceedings of the National Academy of Sciences of the United States of America, vol. 74, no. 12, pp. 5463-5467. http://dx.doi.org/10.1073/ pnas.74.12.5463. PMid:271968.

SANTOS, T.C.M., LOPES, G. P., CARVALHO NETO, A.S., VALSECHI, J., MARQUEZ-AGUIAR, A., 2015. New records of Cynomops planirostris (Peters, 1865) (Chiroptera, Molossidae) for the state of Amazonas and its updated distribution in Brazil. Check List, vol. 11, no. 6, pp. 1-5. http://dx.doi.org/10.15560/11.6.1787.

SILVA, C.R., MARTINS, A.C.M., CASTRO, I.J., BERNARD, E., CARDOSO, E.M., LIMA, D. S, GREGORIN, R., ROSSI, R.V., PERCEQUILLO, A.R. and CASTRO, K. C., 2013. Mammals of Amapá State, Eastern Brazilian Amazonia: a revised taxonomic list with comments on species distributions. Mammalia, vol. 74, no. 4, pp. 409-424. http://dx.doi.org/10.1515/mammalia-2012-0121.

SIMMONS, N.B. and VOSS, R.S., 1998. The Mammals of Paracou, French Guiana: a Neotropical lowland rainforest fauna. Part 1. Bats. New York: American Museum of Natural History. Bulletin of the American Museum of Natural History, no. 237,219 p.

VIZOTTO, L.D. and TADDEI, V.A., 1976. Notas sobre Molossops temminckii temminckii e Molossops planirostris (ChiropteraMolossidae). Naturalia (São José do Rio Preto), vol. 2, pp. 47-59. 